\title{
A modernidade como "Trauerspiel". Representação da história em W. Benjamin, "Origem do drama barroco alemão"
}

\section{Willi Bolle}

Departamento de Letras Modernas FFLCH/USP

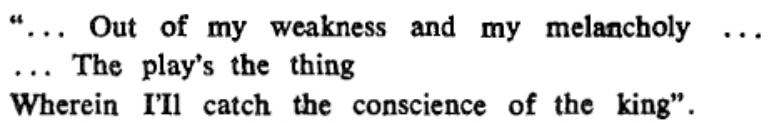

(Shakespeare, Hamlet)

No ensaio “A Modernidade" (1938), espécie de síntese do complexo "Trabalho das Passagens", Walter Benjamin define a época de Baudelaire - e por afinidade, sua própria - com uma metáfora barroca, teatral:

\footnotetext{
"A modernidade heroica revela-se como um Trauerspiel, em que o papel de herói está à disposição" (GS I, 600).1
}

A comparação "Modernidade = Trauerspiel" (o drama barroco, onde reina a Melancolia) apresenta em conjunção os conceitos-chave das duas principais obras do autor: o "Trabalho das Passagens" (1927-1940) e "Origem do drama barroco alemão" ou "Trauerspielbuch" (1916-1928). Explicitar o sentido da imagem levaria a compreender o arcabouço teórico da obra inteira de Benjamin e a esclarecer algumas questões básicas: Qual o valor de conhecimento desse pensamento imagético que é a crítica alegórica? O que significa o código da Melancolia enquanto expressão de uma visão pessimista da história? Como é que o trinômio alegoriamelancolia-drama barroco se articula com os gêneros literários urbanos da Modernidade? 
Devido à singularidade de sua concep̧̧ão - um estilo acadêmico combinado com uma ensaística fragmentária, e um caótico hermetismo com críticas contundentes - o "Trauerspielbuch" provocou uma áspera recepção. Apresentado, em 1925, como tese de livre-docência à Universidade de Frankfurt, o trabalho foi recusado. Mais tarde, a partir do final dos anos 1960, a Universidade alemã passou a aceitar uma série de teses sobre a obra de Benjamin; no entanto, estudiosos recentes do "Trauerspielbuch", como WITTE 1976 e RUMPF 1980, negam-lhe as qualidades de um trabalho de "ciência literária"." Acresce que em histórias literárias e pesquisas especializadas sobre o Barroco, a contribuição de Benjamin continua sendo frequentemente ignorada. Sem dúvida, o "Trauerspielbuch" foi recebido demasiadamente dentro de uma expectativa-padrão em relação a trabalhos acadêmicos; com isso ficou relegada a um plano secundário sua importância como crítica da cultura. Com efeito, como já ocorrera com "O Nascimento da tragédia" (1871) de Nietzsche, também no caso de Benjamin, a tese universitária foi o terreno escolhido para formular, a partir dessa célula-chave da cultura que é a ciência acadêmica, uma crítica mais abrangente da vida cultural como um todo. Para tal fim, revela-se particularmente apropriado o modelo teatral. Ao apresentar a idéia do "Trauerspiel", Benjamin não se propõe "nada menos do que a descrição de uma imagem abreviada do mundo" (GS I, 228). Assim se expressa a intenção de uma crítica alegórica, para a qual a literatura se torna uma forma de historiografia ou, na expressão de Benjamin, um "órganon da história" (GS III, 290).

Como decifrar o código benjaminiano da crítica alegórica? (Conforme declarou o autor em carta de 1924, ele costumava "mascarar os elementos atuais e políticos de seu pensamento"). Seria conveniente que nosso roteiro de leitura seguisse inicialmente a ordem de composição do "Trauerspielbuch", contudo de uma forma suficientemente livre para poder apreender o espírito da crítica alegórica que é um trabalho de desmontagem de fragmentos e remontagem, escolhendo-se uma idéia-guia que reorganize os fragmentos em uma nova constelação. Essa idéia, a interpretação do "Trauerspielbuch" como um "órganon" da história de seu tempo, seria a reflexão sobre a experiência da Guerra Mundial de 1914/18, pela qual passou a geração de Benjamin, então com vinte e poucos anos, e a crítica da restauração cultural e política que ele observou, na Alemanha de 1919 em diante sob o nome emblemático "República de Weimar".

O "Trauerspielbuch" se compõe de um prólogo sobre Crítica do Conhecimento e de duas partes, intituladas respectivamente "Trauerspiel e tragédia" e "Alegoria e Trauerspiel", cada uma com três capítulos. 
São, portanto, ao todo sete capítulos, subdivididos em vários segmentos, como "Barroco e Expressionismo", "História como teor do Trauerspiel", "O trágico e a Melancolia", "Origem da alegoria moderna", "A personagem alegórica", etc. No segmento "Barroco e Expressionismo", Benjamin fala em "notáveis analogias" entre a sensibilidade barroca e moderna, e na

"atualidade do Barroco depois do colapso da cultura clássica alema" (GS I, 235).

Como relâmpagos surgem no emaranhado desse fechado tratado filológico frases fustigantes como esta, reatando com o espírito da "Kulturkritik" nietzscheana, no sentido de completar o retrato da Alemanha guilhermina: um estado autoritário que se iniciou e terminou com uma guerra. O "colapso", para a geração de Benjamin, era o choque brutal entre a expectativa dos estudantes formados segundo o ideal das humanidades clássicas, e a realidade dos campos de batalha para onde foram enviados, de 1914 em diante.

$\mathrm{Na}$ pesquisa acadêmica de seu tempo, Benjamin observa "Negligência e desprezo da tragédia barroca". Investigando o "esquecimento" e obscurecimento do drama barroco, ele revela um significativo processo de recalque cultural. E como se decifrasse, unindo a perspicácia do filólogo à leitura onírica dos surrealistas, o pesadelo do humanismo idealista em relação à tradição anti-clássica: o horror à barbárie e à violência, manifestações que o Barroco - ao invés de encobrílas com teorias harmoniosas - cultiva e ostenta. O "T'rauerspielbuch" revela

“o Barroco como antagonista soberano do Classicismo" (GS I, 352).

Ao mito do Classicismo de Weimar - à tentativa oficiosa de restaurar, depois da Grande Guerra, o legado cultural de Goethe e Schiller, como se tudo tivesse permanecido incólume, e projetar uma cultura setecentista, palaciana e provincial, sobre o mundo das metrópoles modernas - a esse mito, Benjamin opõe as marcas da história recente: guerra e pós-guerra, trauma da derrota e culpa, revolução frustrada, inflaçāo galopante, pauperização, assassinatos políticos. Sobre esses acontecimentos, ele se manifesta em textos paralelos ao "Trauerspielbuch", como "Crítica da violência" (1921) ou "Panorama imperial - Viagem pela inflação alemã" (1923/27). Eles constituem o subtexto moderno das observações sobre o barroco, espaço-tempo para onde se desloca o crítico historiografo para melhor identificar a fisionomia de sua época. 
“Destruição do éthos histórico"

$\mathrm{Na} 1$. $^{*}$ parte do livro, dedicada à diferenciar tragédia clássica e "Trauerspiel", Benjamin esclarece em que medida este é representação da história:

\footnotetext{
"Seu teor, seu objeto autêntico, é a vida histórica, como aquela época a concebia".

"No século XVII, o termo 'Trauerspiel' se aplicava tanto à obra dramática como aos acontecimentos históricos" (GS I, 242-243 e 244; TR 86 e $87 \mathrm{c} / \mathrm{i}) .3$
}

O teor histórico específico do Trauerspiel é a monarquia absolutista. A definição do dramaturgo barroco Opitz (1650) especifica os temas:

"a vontade dos reis, assassínios, desesperos, infanticídios e parricídios, incêndios, incestos, guerras e insurreições, lamentações, gemidos e outros semelhantes" (GS I, 242; TR 86).

A representação da história é representação do poder e tão centrada na personagem do príncipe - "o soberano representa a história" - quanto o poder do Estado está concentrado nas mãos do monarca. Reflexo da teoria política do Absolutismo, o drama barroco alemão é antes de mais nada: apologia dos soberanos. Parece que os autores não tomaram posição crítica .

O que significa a evocação do Absolutismo para o conhecimento da Modernidade alemã dos anos 1920; qual a relação entre tempo representado e tempo de representação? Na nomenclatura benjaminiana, o poder absolutista é um dos "teores históricos factuais" (historische Sachgehalte), um dos elementos de realidade que entram como materiais na construção do drama barroco. A tarefa da crítica consiste em "transformar os teores históricos factuais em teores filosóficos de verdade" (philosophische Wahrheitsgehalte) (cf. GS I, 358; TR 204). Isso significa em síntese: identificar ou "reconhecer" os teores históricos daquela época dentro de um outro tempo. O sentido desse "reconhecer" fica claro à luz do conceito de "origem" (Ursprung):

"O ritmo da origem só se revela a uma visão dupla, que o reconhece, por um lado, como restauração e reprodução, e por outro lado e por isso mesmo, como incompleto e inacabado". 
"O autêntico - o selo da origem nos fenômenos - $-\epsilon$ objeto do uma descoberta que se relaciona, singularmente, $\infty \mathrm{m}$ - reconhecimento" (GS I, 226 e 227; TR 68 c/i).

A história é vista a partir de um conceito de tempo incompleto e inacabado, portanto: uma historia aberta, sujeita a transformaçð̋es. Aqui está o germe de uma filosofia que se opõe às visões míticas de uma história cíclica, imutável. Mais tarde, nas teses "Sobre a filosofia da história", Benjamin retoma essa concepção em termos de um "tempo de agora", capaz de se alimentar de energias de transformação que ficaram suspensas no passado. Ao conceito benjamianiano de história é, pois, inerente algo de inconcluído e imperfeito -

"A história, com tudo o que desde o início ela tem de extemporâneo, sofrido, malogrado"... (GS I, 343; TR $188 \mathrm{c} / \mathrm{i}$ ).

- o que vem a ser uma história dos vencidos, como anti-história a dos vencedores.

Com a análise da visão absolutista do poder, Benjamin visa a crítica das teorias modernas do estado de exceção e da ditadura (ver o segmento "Teoria da soberania"):

\footnotetext{
"Enquanto o conceito moderno de soberania resulta no exercício de um poder executivo supremo, pelo Príncipq, o do Barroco nasce do uma discussão sobre o estado de exceção"

"Quem reina já está desde o início destinado a exercer poderes ditatoriais, num estado de exceção, quando este é provocado por guerras, revoltas ou outras catástrofes" (GS I, 245-246; TR 89 c/i).
}

Benjamin estava preocupado com a existência de fortes elementos autoritários na República de Weimar: estruturas jurídicas, administrativas, militares e policiais, comprometidos com o ancien régime. Atentamente ele acompanhou os estudos do jurista Carl Schmitt que preparou, naqueles anos, uma legitimação da ditadura contemporânea. Sua crítica se opốe ao pensamento de Schmitt, na medida em que procura tornar transparentes os elementos míticos na teoria do poder.

"Mito", na acepção mais frequente de Benjamin, pertence à mesma esfera semântica que "Poder" e "Violência". Uma leitura comparada do "Trauerspielbuch" e do ensaio "Crítica da violência - crítica do 
poder" (1921) podo elucidar melhor a relação entre as reflexões benjaminianas sobre o drama barroco e a realidade alemã da Guerra Mundial e 'dos primeiros anos de pós-guerra. A intenção do ensaio - inteiramente construído sobre a ambiguidade da palavra "Gewalt" ("violência" e "poder") - é mostrar a origem do direito, enquanto legitimação do poder, a partir do espírito da violência..

“A institucionalização do direito é institucionalização do poder e,
nesse sentido, um ato de manifestação imediata da violência. A jus-
tiça é o princípio de toda instituição divina de fins, o poder (Macht)
é o princípio de toda institucionalização mítica do direito" (GS II,
198; DCDB 172) ${ }^{+}$

Em nome da instância transcendental de um poder divino "puro", o crítico denuncia o direito no Estado moderno como comprometido com o poder, não com a causa da justiça. As instâncias que garantem o status quo são o militarismo (que é "a compulsão para o uso generalizado da violência como um meio para os fins do Estado", GS II, 186; DCDB 164) e o poder da polícia: "A infâmia dessa instituição... consiste em que ali se encontra sus-
pensa a separação entre poder instituinte e poder mantenedor do
direito.

'Por questōes do segurança', a polícia intervém em inúmeros casos, em que não existe situação jurídica definida, sem falar dos casos em que a polícia acompanha ou simplesmente controla o cidadão, sem qualquer referência a fins jurídicos, como um aborrecimento brutal, ao longo de uma vida regulamentada por decretos.

Seu poder $\varepsilon$ amorfo, como é amorfa sua aparição espectral, inatacável e onipresente na vida dos países civilizados" (GS II, 189; DCDB 166).

O ponto de chegada da "Crítica da violência" é "a ruptura da trajetória das formas míticas de direito" - idếia que reaparece na forma de imagens revolucionárias, nas teses "Sobre o conceito de história": "fazer explodir o continuum da história", "parar (ou: congelar) o tempo" e "criar o estado de exceção de verdade".

Os recursos expressivos do drama barroco alemão - essencialmente voltado para a apologia do poder - estão subordinados a uma visão mítica, imutável da história. E o que Benjamin chama de "destruição do éthos histórico". Retomando a postura medieval de fuga do mundo 
e o tópos da desvalorização da vida mundana, o Barroco o readapta no sentido de substituir a perspectiva de uma história da salvação por uma visão da história como história natural.

"O que é decisivo na tendência barroca de fugir do mundo ... é a secularização da história no estado de Criação. Ao percurso desolador da crônica do mundo não se contrapõe a eternidade, mas a restauração de uma intemporalidade paradisíaca" (GS I, 271; TR $115 \mathrm{c} / \mathrm{i}$ ).

As leis da história enquanto história natural estão sujeitos todos os mortais - o que pode sugerir que existam condições semelhantes entre soberano e súditos. Na verdade, a visão da história como história natural sanciona o status quo do poder para sempre. A emblemática e os demais recursos alegóricos dos dramaturgos barrocos alemães - Opitz e Gryphius, Lohenstein, Hallmann e Haugwitz - estão inteiramente presos dentro da esfera absolutista do poder.

\footnotetext{
"Os autores tinham à sua disposição um grande repertório imagético, graças ao qual podiam dissolver convincentemente conflitos históricos, éticos, em demonstrações baseadas na história natural" (GS I, 269; TR $113 \mathrm{c} / \mathrm{i})$.

"E Lohenstein que vai mais longe nessa direção. Nenhum outro poeta usou como ele a técnica de desarmar qualquer início de reflexão ética, por meio de uma linguagem metafórica que postula analogias entre o acontecimento histórico e o natural" (GS I, 268; TR $112 \mathrm{c} / \mathrm{i}$ ).
}

Desse ciclo de uma visão mítica da história, nenhum dos dramaturgos barrocos alemães escapou. Porém, através da comparação com outros autores do mesmo período, Calderón e Shakespeare, o crítico mostra que havia frestas no jogo da representação dramática para se questionar as normas do Absolutismo ao invés de obedecer-lhes de modo servil (ver os segmentos "Jogo e reflexão" e "Hamlet").

A visão crítica do "destruição do éthos histórico" é projetada, por Benjamin, do drama barroco sobre os procedimentos da pesquisa acadêmica na Alemanha guilhermina. Ao discutir a teoria da tragédia de pesquisadores seus contemporâneos, Benjamin denuncia a

“eliminação da filosofia da história” (GS I, 280; TR 125).

A indevida confusão dos gêneros "tragédia clássica" e "Trauerspiel", por parte dos pesquisadores, contribuiu a obscurecer as peculiaridades de 
feitura e função de cada uma dessas formas dramáticas. Uma ciência acadêmica que não cultiva a análise histórica das formas e dos estilos literários - essa é a crítica global que Benjamin dirige à ciência literária de seu tempo (ct. GS I, 231; TR 73) - faz o jogo de uma 'destruição do éthos histórico', característico de estados autoritários. Dentre os estudos da época, a "Estética do trágico", de Johannes Volkelt (3." ed. 1917) é comentada como uma "codificação exemplar dos preconceitos" e das limitações:

"Sem qualquer respeito pelos fatos históricos, a filosofia da tragédia foi construída como uma teoria da ordem ética do mundo, dentro de um sistema de sentimentos genéricos, solidamente apoiados, ao que se julgava, em conceitos como 'culpa' e 'expiação'” (GS I, 279; TR 123-124 c/i).

Benjamin recusa a relação irrefletida entre uma tragicidade genérica e um vago universo sentimental do "homem moderno". Desafiando a pesquisa ahistórica, ele postula que "uma teoria da tragédia só se pode esperar, onde a pesquisa chegou a uma compreensão da própria época".

Nas pesquisas acadêmicas típicas do início deste século, o crítico verifica a ausência dessa compreensão de época. Ela existia no trabalho de Nietzsche, "O Nascimento da tragédia" (1870/71), que procura compreender a crise da cultura na Modernidade através de um confronto com a visão trágica dos antigos. Porém, Benjamin não compartilha com Nietzsche a fé num renascimento da cultura trágica. Ele critica, no "Nascimento da tragédia", uma visão mítica, esteticista, que se instaurou maciçamente entre os epígonos. A compreensão do mito na tragédia, por parte de Nietzsche, acha se comprometida, segundo Benjamin, pela fundamentação no esteticismo e o afastamento de uma análise histórica. De fato, em duas passagens cruciais de seu livro, Nietzsche afirma sua adesão a uma metafísica da arte:

"Apenas como fenômeno estético a existência e o mundo parecem se legitimar" (Nascimento da tragédia, 40 e 131)."

Benjamin comenta:

"Abre-se o abismo do esteticismo, no qual essa intuição genial acabou perdendo todos os conceitos" (GS I, 281; TR $126 \mathrm{c} / \mathrm{i}$ ).

Ele mostra, em particular, como a tese nietzscheana do "renascimento do mito trágico" passa por cima de evidências históricas - o trabalho 
detalhado de transformação que a tragédia clássica sofreu no Barroco e identifica a restauração da antiguidade clássica pelo Idealismo alemão e seus seguidores como mera "recriação da cultura humanística erudita". Uma ciência acadêmica assim fechada dentro dos parâmetros do esteticismo mostra-se incapaz de decifrar, através da leitura das formas estéticas, a realidade histórica onde essas formas são produzidas.

História de uma emoção: Melancolia

A distinção dos dois gêneros, tragédia e "Trauerspiel", se torna muito clara no momento em que Benjamin discute, lado a lado, a função histórica das emoções que constituem seu núcleo: "Tragik" (o trágico) e "Trauer" (o luto, a melancolia) (v. o segmento "O trágico e o luto"). - Diferentemente de Nietzsche, que interpreta a tragédia clássica a partir dos impulsos estéticos do dionisíaco e do apolíneo, Benjamin confronta a tragédia com teores factuais históricos - estruturas de direito e poder -, mostrando que ela desempenha uma função emancipadora.

Também no caso do "Trauerspiel", Benjamin visa a função histórica do uso das emoções em espetáculos públicos. Qual era a função política do luto e da melancolia no drama barro alemão? Benjamin esclarece:

Trauerspiele "não são tanto peças que provocam a melancolia, como peças graças às quais a melancolia encontra uma satisfação: peças para melancólicos. Uma certa ostentação lhes é inerente. Seus quadros são organizados para serem vistos, ordenados, na forma com que querem ser vistos. Assim o teatro renascentista da Itália, que de tantas maneiras influenciou o Barroco alemão, emergiu da pura ostentação, ou seja, dos 'trionfi', as procissões acompanhadas de recitativos, surgidas em Florença sob Lorenzo de Medici” (GS I, 298; TR 142 c/i).

Nascido de procissões triunfais, o drama barroco é um ritual de representação do poder, em que o estético está a serviço do político. Pura ostentação, esse drama serve à glorificação do soberano. Em sua origem, portanto, nenhuma melancolia genuína. A melancolia é elemento de encenação. A exibição do luto e da melancolia é uma forma oficial como deve ser vista a história, expressão de um pessimismo oficial da história, elemento-chave de legitimação do poder (v. o segmento "Teoria da legitimação”) .

O pessimismo oficial da história — a visão da história como "Trauerspiel" - vinha de longa data; Benjamin cita as fontes medievais da crônica e do drama dos mártires. Com razão afirma ele que na teoria 
da constituição melancólica, "a posteridade possui um comentário mais preciso do 'Trauerspiel' do que poderiam oferecer as teorias poéticas. O ritual teatral é inteiramente estilizado em função das necessidades do poder. Assim, o tópos da "Melancolia do príncipe":

"O Príncipe é o paradigma do melancólico" (GS I, 321, TR 165).

Ou, a organização dos quadros dramáticos, que ilustram como a melancolia se presta à ostentação:

"Na via para o objeto - ou melhor, dentro do próprio objeto essa intenção |a do luto, da melancolia) avança tão lenta e tão solenemente como as procissões dos soberanos" (GS I, 318; TR $163 \mathrm{c} / \mathrm{i}$ ).

A pompa da autoridade e a solenidade hierática aparecem como características principais; e uma ênfase persuasiva, hipnótica:

“O que caracteriza o 'Trauerspiel' não é portanto a imobilidade, nem a lentidão, ... mas o ritmo intermitente de constantes paradas, uma súbita reviravolta e um novo congelamento" (GS I, 373; TR 220-221 c/i).

Esse era o lado dos poderosos; e os espectadores, o público comum, os súditos? Benjamin lembra que os grandes dramaturgos alemães do Barroco eram luteranos:

"O luteranismo conseguiu sem dúvida instalar no povo uma rigorosa obediência ao dever, mas entre os grandes instilou a melancolia" (GS I, 317; TR 161).

$\mathrm{Na}$ procura de sentido num mundo esvaziado de sentido, a proposta do luteranismo, segundo Benjamin, foi esta:

"Não havia resposta, a não ser a moral dos humildes - 'cuidar das coisas pequenas', 'viver honestamente' - que se desenvolveu na época e se contrapôs ao taedium vitae dos ricos" (GS I, 318; TR 162 c/i).

Assim, a interpretação religiosa do Barroco - com sua desvalorização do mundo e ênfase no dever e na obediência dos súditos - estava bem articulada com a teoria da legitimaçăo do Absolutismo. A "anestesia das paixões" e a "mortificação do corpo" configuram uma patologia oficial, promovida pelas autoridades eclesiásticas e mundanas. 
Não ocorre em nenhum momento, no drama barroco, a virada dialética, do austero uso mítico da melancolia para uma visão crítica? Benjamin sugere uma pista:

"A teoria do luto, que emergiu como contrapartida da teoria da tragédia, só pode ser desenvolvida por meio da descrição do mundo que se abre ao olhar melancólico" (GS I, 318; TR 162-163).

Nas passagens benjaminianas sobre a Melancolia - a "Melancolia illa heroica", de Melanchton - unem-se, como nos melhores momentos do drama barroco: jogo e reflexão. Ludicamente emerge da imagem do Príncipe como paradigma do melancólico, seu duplo: o poeta, o ator. As imagens do representante do poder e do melancólico de verdade convergem na figura de Hamlet. Nesse personagem e só nele, segundo Benjamin, a melancolia encontra a si mesma, chega ao autoconhecimento. Na rede da representação teatral, o pensamento melancólico capta, mimeticamente, a violência mítica da história oficial. Provavelmente podemos ler as passagens sobre a Melancolia (sobre "Hamlet" e a "gravura de Duerer) - o capítulo central do livro - como um alegórico auto-retrato do crítico-escritor. Jogo e reflexão, o palco e o gabinete do pesquisador, o "gênio da Melancolia alada" e a "vida interior desse teatro". As alegorias barrocas do cão ("faro e perseverança"), da esfera ("poder de concentração") e da pedra ("a inércia do coração", "a traição", "a contemplação") revelam traços fisionômicos do intelectual moderno.

"O drama barroco alemão não soube adquirir uma verdadeira alma, nem despertar em seu interior a clara luz da autocompreensão. Permaneceu surpreendentemente obscuro para si mesmo..." (GS I, 335: TR 180).

Nestes termos, Benjamin formula o desafio para o escritor de textos melancólicos: conhecer-se a si mesmo. Os dramaturgos barrocos alemães não chegaram a esse ponto. E legítimo supor que a penetrante análise benjamiana das imagens da melancolia, no drama barroco e na gravura de Duerer - com a projeção da imagem do pesquisador - é uma representação alegórica da situação da inteligência literária na República de Weimar.

"Há indícios de que o auto-retrato de Benjamin como um melancólico não visa a análise de uma idiossincrasia pessoal, mas de um 'caráter social'... uma 'conscience malheureuse' do intelectual moderno, 0 qual, privado de qualquer possibilidade de atuação prática, fica relegado à reflexâo sobre si mesmo e o mundo... Os sintomas de auto-alienação e despersonalização não são elementos autobiográficos gratuitos, mas 
apontam um estado de coisas social: a perda de função da intelectualidade literária na sociedade moderna" (WITTE 1976, 135-136).

Em dois momentos decisivos da recente história alemã - o trauma da Guerra Mundial, seguindo do malogro da Revolução de 1918 (a qual, embora trouxesse a República, não rompeu com as forças do antigo regime autoritário) e a implantação da ditadura nacional-socialista, de 1933 em diante - Benjamin e sua geração se defrontaram com o desafio de não deixar a melancolia provocada pela situação vigente deteriorar-se em resignação. Desafio que Brecht formulou laconicamente nestes versos:

\footnotetext{
"Nos terremotos que virão, tenho a esperança

de não deixar apagar meu 'Virgínia' por amargura". ${ }^{6}$
}

Benjamin, no "Trauerspielbuch" e em outros textos do mesmo período, busca uma saída que, em princípio, é teológica; mas logo começam a se delinear formas de revolta. Duas versōes do texto "Panorama imperial. Viagem pela inflaçẫo alemã" ilustram a evolução de seu pensamento:

"Nunca, porém, deve o indivíduo fazer as pazes com a pobreza, quando ela se abate... como uma sombra gigantesca sobre seu povo e sua casa. Ele deve ficar com os sentidos despertados para qualquer humilhação que eles venham a sofrer e manter a disciplina até o dia em que seu sofrimento tiver aberto não mais a estrada descendente do ODIO, mas o caminho ascendente da ORAÇĀO".

Esta é a primeira versão, de 1923; a segunda, de 1927, diz:

“... Ele deve ficar com os sentidos despertados para qualquer humilhação que eles venham a sofrer e manter a disciplina até o dia, em que seu sofrimento tiver aberto não mais a estrada descendente da MELANCOLIA, e sim, o caminho ascendente da REVOLTA" (GS IV, 923 e 97; grifos W. B.).

A substituição de "oração" por "revolta" é indício de uma mudança, da perspectiva teológica para a expectativa de uma Revolução. No tempo de redação do "Trauerspielbuch", Benjamin começa a travar contato com leituras marxistas (como Lukács, "História e consciência de classe") e figuras militantes (como Asja Lacis, diretora de teatro na URSS) prelúdios para uma viagem a Moscou em 1926/27, para o contato com Brecht, para o acompanhamento das atividades da BPRS (Associação dos Escritores Proletários-Revolucionários). Contra esse pano de fundo deve 
ser vista sua atuação como crítico militante, de 1926 em diante, e em particular ,a contundente resenha publicada em 1931 sob o título "Melancolia de esquerda".

Peça de aprendizagem do código da Melancolia, o "Trauerspielbuch" foi para Benjamin uma espécie de exorcismo de um complexo processo social de recalque: a história enquainto história da violência e do sofrimento. Com o estudo das formas da melancolia ao longo dos séculos, o crítico adquiriu uma sólida base para poder discernir entre manifestações autênticas de melancolia e a melancolia "representada" ou melancolia de pose. No caso da resenha, embora se trate especificamente de um livro de poemas de Erich Kaestner, a crítica de Benjamin visa todo um grupo de "autores radicais de esquerda, do tipo Kaestner, Mehring ou Tucholsky", denunciando neles uma postura que "converte reflexos revolucionários em objetos de distração e consumo". Ainda que essa crítica em bloc cometa algumas injustiças - sobretudo em relação a Tucholsky - ela é válida como retrato de um caráter social e fornece critérios técnicos para desmascarar formas de melancolia acomodada ou melancolia venal. Qual a posição do escritor em relação a seus leitores e às classes sociais representadas nos textos? Nos poemas de Kaestner, o crítico verifica uma atitude servil em relação ao público comprador e uma incapacidade de extrair da melancolia alguma forma autêntica de revolta:

\footnotetext{
"A essa camada social la dos altos e médios funcionários de colarinho branco] ficam restritos a temática e os efeitos de Kaestner, igualmente incapaz de atingir com seus acentos rebeldes os que não possuem nada, quanto com sua ironia os industriais" (GS III, 279; DCDB $138 \mathrm{c} / \mathrm{i}$ ).
}

A melancolia aparece como uma emoção postiça, estereotipada, que não leva a conhecimento algum da realidade social, apenas a uma poesia sem gume, dentro da percepção rotineira de uma camada social.

"O ritmo das estrofes de Kaestner segue o mesmo compasso em que os pobres milionários choram sua tristeza; dirigem-se à melancolia dos saturados que não podem investir todo o seu dinheiro para encher sua barriga. Estupidez atormentada: eis a última das metamorfoses da melancolia em sua história de dois mil anos" (GS III, 282-283; DCDB 140).

A moderna melancolia dos ricos e saturados lembra o tópos barroco do Príncipe como paradigma da melancolia e se torna emblema de uma poesia niilista de consumo, em acordo com o status quo. No fundo dos textos 
dos "melancólicos de esquerda" ou "rotineiros da Revolução", o crítico detecta uma decadência da sensibilidade:

\begin{abstract}
"A melancolia de Kaestner nasce da rotina. Pois ser rotineiro significa ter sacrificado suas idiossincrasias, ter renunciado à capacidade de sentir nojo. E isso que torna as pessoas melancólicas" (GS III, 280; DCDB 139).
\end{abstract}

E a "inércia do coração", a "acedia" medieval e barroca, redescoberta por Benjamin entre seus contemporâneos. A rotina das percepçōes leva a um encouraçamento emotivo, o medo de ser vulnerável, a um fazer as pazes com os choques do cotidiano.

Nos últimos anos de sua vida, depois da derrota da crítica militante pelo nacional-socialismo, Benjamin, na condição de escritor exilado, se volta para a poesia de Baudelaire, numa segunda grande tentativa de aprendizagem do código da Melancolia. Não mais a Melancola de que nasce a Revolta, mas a organização de uma Memória da Melancolia. Em Baudelaire, Benjamin encontra uma constelação emotiva que caracteriza a classe média no início da Modernidade, vale dizer: no início de sua decadência. Ele se propõe escrever a história dessa decadência. Em "Notes sur les Tableaux parisiens de Baudelaire", de 1939, ele diz:

"Il parait que, par échappées, Baudelaire ait saisi certains traits de cette inhumanité à venir. On lit dans les 'Fusées': 'Le monde va finir... Ce n'est pas particulièrement par des institutions politiques que se manifestera la ruine universelle... Ce sera par l'avilissement des coeurs" (GS I, 747-748).

Esse “aviltamento dos corações" não é a forma moderna da "acedia"? Em Baudelaire, Benjamin ainda encontra a atenção do coração, a disposição do poeta de ser vulnerável:

"Le désespoir fut la rançon de cette sensibilité qui, la première abordant la grande ville, la première en fut saisie d'un frisson que nous, en face de menaces multiples, par trop précises, ne savons même plus sentir" (GS I, 748).

A postura heroica de Baudelaire consistiu em organizar essa sensibilidade, a melancolia moderna, em meio à experiência de choque. Ao escrever a história dessa experiência poética, no "Trabalho das Passagens", Benjamin avalia o grau de decadência das emoções de que foi testemunha. 
"Im Faltenschoss der alten Metropolen, Wo Feen im Entsetzen selber walten, Folgt meine truebe Leidenschaft verstohlen Verfallnen, doch vollendeten Gestalten" (Baudelaire, Les petites vieilles; trad. W. Benjamin).

Da alegoria barroca à alegoria moderna

Organização da melancolia significa para o autor do "Trauerspielbuch": crítica alegorica. A II.a parte do livro, intitulada "Alegoria e drama barroco" é dedicada à análise do traço estilístico dominante. O drama barroco é uma sequência de "alegorias em movimento", a alegoria é "ação dramática congelada" e "metáfora traduzida em linguagem cênica" (368). Ao tema tratado - a alegoria barroca como precursora da moderna estética do fragmentário - corresponde uma forma fragmentária de exposição, com uma superposição de tempos históricos bastante caótica. Uma remontagem dos segmentos da II.a parte do livro permite esboçar um histórico da alegoria e abordar alguns aspectos técnicos.

"Origem da alegoria moderna" (a rigor: "Origem da alegoria mais recente") é o segmento que pode servir de introdução. Não se trata ainda da modernidade de Baudelaire ou de Benjamin, mas da alegoria renascentista e barroca, em contraposição à alegoria medieval. Benjamin mostra a evolução, baseando-se no estudo de GIEHLOW 1915 sobre o uso dos hieróglifos no arco de triunfo do Imperador Maximiliano I. Na Idade Média, a função da alegoria era didática-cristã: elaboração de imagens a serviço da teologia. O segmento "O Corpo dos deuses no Cristianismo" esclarece:

"Há uma tríplice afinidade objetiva entre o cristianismo barroco e medieval. Em ambos, são igualmente necessários a luta contra os deuses pagãos, o triunfo da alegoria e o martírio do corpo. Esses temas estão estreitamente correlacionados. Sob o aspecto da história da religião, constituem um tema único. E só nessa perspectiva pode a origem da alegoria ser esclarecida" (GS I, 394; TR 243-244 c/i).

A elaboração da alegoria medieval implica a "dissolução do pantheon dos antigos". Isso significa: juntamente com a desvalorização da imagem dos deuses antigos é proscrito o culto do corpo .Segundo a convenção medieval, os deuses pagãos são "de natureza demoníaca" e a sedução do corpo é combatida com sua "mortificação"; um exemplo é a figura de Venus, transformada em alegórica "Dama-Mundo". 
O uso da alegoria como técnica imagética de desvalorização implica - além de seu compromisso com a autoridade eclesiástica - um aspecto crítico. A redução de deuses a uma dimensão humana, imperfeita, deixa entrever um princípio geral: a fabricação de imagens de deuses e outras autoridades supremas é uma questão de domínio da técnica e de sua reprodutibilidade.

A elaboração da alegoria barroca se dá em meio ao conflito entre o legado medieval e a revaloração da Antiguidade clássica pela Renascença. (Aliás, mesmo desvalorizando os deuses antigos, a alegoria medieval os "salvou" para a memória da posteridade). Com os trabalhos dos humanistas do século XVI, de deciframento de um corpus de escrita hieroglífica - enigmática e sagrada - a alegoria firma-se como Escrita: imagética, iconográfica, ideogramática.

"Partindo da exegese alegórica dos hieróglifos egípcios, na qual lugarescomuns derivados da filosofia da natureza, da moral e da mística substituíam os dados da história e do culto, os literatos começaram a elaborar essa nova escrita" (GS I, 345; TR 190-191 c/i).

Como é que o Barroco trabalha com o legado humanista de iconologias, emblemas, rébus, ideogramas?

"Nas produções do Barroco maduro torna-se cada vez mais nítida a distância em relação aos inícios da emblemática, um século antes, cada vez mais fugaz a semelhança com o símbolo, e cada vez mais imperiosa a ostentação hierática" (GS I, 346; TR 191 c/i).

A ostentação, como procedimento dominante da alegoria barroca, é o gestus do poder. Como a autoridade eclesiástica, depois das lutas religiosas estava abalada, o gestus hierático foi incorporado pela autoridade mundana do Absolutismo. Por outro lado, a "pomposa ostentação" cede - lugar a uma "desoladora fisionomia do cotidiano" (GS I, 361; TR $207 \mathrm{c} / \mathrm{i})$. No segmento "Antinomias da alegorese", Benjamin mostra como a alegoria não é apenas "expressão da autoridade", mas também: "expressão da falta de liberdade":

"Na esfera da intenção alegórica, a imagem é fragmento, runa... Nos rébus áridos que ficam, existe uma intuição, acessível mesmo ao meditativo mais confuso. Perceber a falta de liberdade, a imperfeição, a caducidade do corpo belo e sensual, era vedado ao Classicismo, pela sua própria essência. São justamente esses elementos que a alegoria barroca apresenta, ocultos sob uma pompa desvairada, com uma ênfase até então desconhecida" (GS I, 352; TR 198 c/i). 
A leitura de Benjamin revela o subtexto da "ostentação barroca": "falta de liberdade, imperfeição e caducidade do corpo belo e sensual". Dessa visão de mundo - sob o signo dả decadência e da fragmentação - nasce o questionamento da totalidade orgânica, defendida pela estética classicista:

\begin{abstract}
"Não se pode conceber contraste maior em relação ao símbolo artístico, ao símbolo plástico, à imagem da totalidade orgânica, que esse fragmento amorfo que é a imagem da escrita alegórica. Aqui, o Barroco se revela como antagonista soberano do Classicismo" (GS I, 351-352; TR $198 \mathrm{c} / \mathrm{i})$.
\end{abstract}

Com essa chave, os diversos elementos técnicos da alegoria - tais como - "acúmulo de fragmentos", os "personagens alegóricos cedendo lugar aos emblemas em triste e desolado estado de dispersão", a representação da violência culminando no emblema do cadáver - podem ser aproximados da estética da Modernidade.

Nos períodos que separam o Barroco da Modernidade, Benjamin observa uma visão negativa da alegoria. Classicismo e Romantismo se empenharam em instaurar uma religião da arte - precursora do l'art pour l'art -, fundamentada numa teoria do símbolo, que Benjamin denuncia como usurpação da autoridade religiosa por uma ideologia esteticista (ver os segmentos "Símbolo e alegoria no Classicismo" e "no Romantismo"). O crítico faz observar que a reconstituição erudita de uma "religião da arte" segundo uma visão idealizada da cultura clássica grega é, sobretudo, uma projeção ideológica da moderna sociedade burguesa. Como disse WARBURG 1920, citado por Benjamin:

"O nobre mundo clássico dos deuses antigos transformou-se para nós de tal maneira, desde Winckelmann, em símbolo da Antiguidade em geral, que perdemos inteiramente de vista que esse mundo foi uma re-criação da cultura humanista erudita; esse lado 'olímpico' da Antiguidade precisou no início ser arrancado do seu contexto tradicional, ‘demoníaco”” (GS I, 400; TR 249).

O lado demoníaco da alegoria é resgatado por Benjamin na figura "arqui-alegórica" de Satanás. Diga-se de passagem que o dilema entre "oração" e "revolta", com o qual ele se defrontava nos anos 1920, tinha sido superado por Baudelaire na forma poética do satanismo (ver "Les Litanies de Satan"). No ensaio sobre o Surrealismo (1929), Benjamin trabalha com esse legado, mostrando como o satanismo de Rimbaud, Lautréamont, Dostoiévski visava dinamitar o idealismo burguês. Nessa linha 
vai também sua leitura de Nietzsche: contra o mito de um renascimento moderno da tragicidade clássica, Benjamin propõe a visão da história sob o signo da decadência e da melancolia, onde a alegoria enquanto "fragmento amorfo" traduz, melhor do que a falsa aparência da totalidade simbolica, a experiência moderna de um tempo de "homens partidos". Assim, a alegoria barroca - enquanto codificação de um mundo violento e vazio de sentido - irrompe na Modernidade. ${ }^{7}$

Baudelaire como poeta aleg6rico

“A alegoria é a armadura da Modernidade" - sentencia Benjamin quando retoma em outro contexto, no final dos anos 1930, os estudos sobre alegoria e alegorização. No projeto de livro sobre Baudelaire - que seria uma condensação do "Trabalho das Passagens" - estava prevista uma parte intitulada "Baudelaire como poeta alegórico" (Baudelaire als Allegoriker); ela não chegou a ser escrita, mas existe um conjunto de esboços e notas, publicado em 1974 sob o nome de "Parque Central" (Zentralpark) ${ }^{8} \mathrm{~A}$ concepção alegórica, esclarece Benjamin, que era, no século XVII, o princípio estilístico dominante, não o é mais no século XIX. Baudelaire como poeta alegórico é um caso isolado, uma espécie de epígono. Como se explica que um procedimento tão "extemporâneo" seja de tamanha importância para a poética da Modernidade?

A re-introdução da alegoria, esclarece Benjamin, responde à crise da arte (que teve suas causas no desenvolvimento tecnológico e na situação política) de maneira muito mais significativa que o "l'art pour l'art"' (cf. GS I, 659; TK 125). A alegoria, para Baudelaire, é uma forma de organizar uma constituição melancólica.

“A expressão de Melanchthon 'Melencolia illa heroica' é a mais perfeita designação do engenho de Baudelaire" (GS I, 689; TK 151).

O "spleen" baudelaireano é "a sensação que corresponde à catástrofe permanente" (GS I, 659-660; TK 125-126). O novo e decisivo elemento que faz com que o "taedium vitae" em Baudelaire se torne "spleen" é "o distanciamento de si mesmo". Elemento ao mesmo tempo patológico e construtivo, que faz com que as "Flores do Mal" se tornem a expressão exata do pessimismo histórico da Modernidade.

As fontes de que se alimenta a postura heroica de Baudelaire são as experiências, através das quais ele se inteirou das "radicais mudanças nas condições de produção artística": 
"Na obra de arte se expressava, de modo mais direto veemente do que nunca, a forma de mercadoria e, em seu público, a forma de massa. ... Baudelaire responde a essas mudanças com um livro de poesia" (GS I, 676; TK 139-140 c/i).

$\mathrm{Na}$ condição de produtor de mercadoria - a mercadoria "poesia" o poeta participa da experiência geral da Modernidade. Ela é o papel por excelência assumido por Baudelaire:

\begin{abstract}
"A Modernidade acabou sendo um papel, que talvez pudesse ser representado apenas pelo próprio Baudelaire. Um papel trágico em que o diletante... muitas vezes parecia cômico. Baudelaire sabia de tudo isso. No fundo, ele não era... nem mesmo um herói. Mas ele tinha algo'do mímico, que tem de representar o papel de "poeta" perante uma platéia e uma sociedade, que já não precisa do poeta autêntico e só lhe concede um espaço de brincar como mímico" (GS I, 662; TK $128 \mathrm{c} / \mathrm{i}$ ).
\end{abstract}

Nos anos 1920 e 30, Benjamin viveu um papel semelhante, enquanto escritor, crítico e pesquisador. O gestus heroico de Baudelaire consistiu em "viver no coração da inautenticidade, isto é: em meio à aparência". A merlização onipresente e todo-poderosa desafia o poeta:

"A desvalorização do mundo das coisas, pela alegoria, é sobrepujada, dentro do próprio mundo das coisas, pela mercadoria" (GS I, 660; TK $128 \mathrm{c} / \mathrm{i})$.

O poeta alegórico se expõe aos choques causados pela degradaçăo das coisas e das pessoas. Usando de simulação lúdica, de uma deformação construtiva, trava a luta - de antemão perdida - contra a publicidade mercantil:

\footnotetext{
"Cada vez mais, o mundo dos objetos assume as feições da mercadoria. Ao mesmo tempo, a publicidade trata de encobrir o caráter mercantil das coisas. 'A enganadora transfiguração do mundo das mercadorias contrapõe-se sua deformação alegórica. A mercadoria procura ver seu próprio rosto. $\mathrm{Na}$ prostituta ela celebra sua transformação em ser humano" (GS I, 671; TK $135 \mathrm{c} / \mathrm{i}$ ).
}

A mercadoria "que procura ver seu próprio rosto" é a poesia. Sobre o projeto poético de Baudelaire de flagrar esse retrato - traçar, através de "regards sur ses contemporains", a fisionomia da metrópole moderna — informa Benjamin: 
"Os temas que constituem o cerne da poesia de Baudelaire não eram acessíveis a esforços planejados e sistemáticos: Esses temas, decididamente novos - a grande cidade, a massa - não eram visados por ele como tais. Não são eles a melodia que ele tinha em mente. $\mathbf{E}$ sim: o satanismo, o 'spleen', o erotismo perverso" (GS I, 667; TK $132 \mathrm{c} / \mathrm{i})$.

Todos esses elementos da poesia urbana de Baudelaire - satanismo, spleen, erotismo perverso - usam a alegoria. O satanismo, além de ser uma das formas da Revolta, é também um emblema do princípio destruidor na arte moderna:

"Baudelaire escreveu alguns de seus poemas, para destruir outros poemas, escritos antes dele".

$\ldots$

"através do uso clássico do alexandrino desvalorizou certas licenciosidades dos românticos; através de rupturas e irregularidades no verso clássico, desvalorizou a poética classicista" (GS I, 688 e 664; TK 150 e $130 \mathrm{c} / \mathrm{i})$.

Uma dessas técnicas de destruição - "arrancar os elementos de seu contexto habitual" - vem a ser uma definição da alegorização barroca e, ao mesmo tempo, um dos princípios básicos da poética da Modernidade: a desmontagem em função de uma nova montagem. Um exemplo perfeito de correspondência entre alegorização barroca e moderna é o poema "A une martyre", onde se entrelaçam o erótico e o mórbido, onde o despedaçamento alegórico "se consuma em todo o seu vigor no cadáver". Esse poema é também um dos "disiecta membra" da história de detetive, gênero literário urbano criado por Edgar A. Poe e sequestrado por Baudelaire, através de uma destruição construtiva, para o lado da "poesia do apache", em que reinam o criminoso e a prostituta:

“' 'L'appareil sanglant de la Destruction' - eis os utensílios dispersos da vida doméstica, os quais - na câmara íntima da criação poética de Baudelaire - estão aos pés da Prostituta herdeira plenipotenciária da alegoria barroca" (GS I, 676; TK $140 \mathrm{c} / \mathrm{i}$ ).

A sensualidade de Venus, desvalorizada e imortalizada pela alegoria medieval e barroca, nas figuras da Dama-Mundo e da Volúpia, ressurge na literatura urbana moderna, na Prostituta de Baudelaire, na "Grande Puta Babilônia" de Doeblin. Nos textos de Benjamin, o detalhe dos "utensílios dispersos da vida doméstica" aos pés de uma alegórica figura feminina leva a uma superposição de imagens: a Prostituição do "Trabalho das 
Passagens" e a Melancolia alada do "Trauerspielbuch". (Grande e único divertimento do melancólico: o jogo com fragmentos, infindável arte combinatória.) Em Baudelaire como em Benjamin, que desmonta e remonta seus fragmentos, surge a imagem da Metrópole moderna como uma alegoria de formas femininas: prostituição e exuberância sensual de um lado, caducidade e decrepitude do outro. A "Passante", "en grand deuil, douleur majestueuse", portadora de "douceur qui fascine" et "plaisir qui tue", e as "Evas octogenárias", "débris d'humanité", "Ruines! ma famille" - são as figuras de identificação que o poeta e o crítico seu duplo perseguem obstinadamente "dans les plis sinueux des vieilles capitales". Elas são vislumbradas através do véu das massas urbanas, imensa procissão de papa-defuntos, no meio dos quais caminha, vestido de luto, o poeta-herói:

\begin{abstract}
"Por falar em roupa, o invólucro do herói moderno ... Será quo não é desta roupa que a nossa época precisa? Pois a nossa época sofre e, ainda por cima, tem de suportar sobre seus magros ombros e negro símbolo de uma eterna tristeza. O terno e a sobrecasaca negros não têm sua beleza política apenas como expressão da igualdade de todos - também têm uma beleza poética, enquanto expressão de um estado de ânimo público, representado por uma infindável procissão de papa-defuntos: papa-defuntos políticos, papa-defuntos eróticos, papadefuntos particulares. Todos nós temos sempre um enterro pela frente" (GS I, 580; TK $101 \mathrm{c} / \mathrm{i}$ ).
\end{abstract}

Todos os procedimentos alegóricos levam à imagem do cadáver:

"A alegoria barroca vê o cadáver só do lado de fora, Baudelaire o vê também de dentro" (GS I, 684; TK 146 c/i).

Olhando o estado interior do homem moderno, o poeta descobre: um morto em vida. O molde dessa visão baudelaireana, assinala Benjamin, estava prefixado na obra de Poe.

"Para quê pregar o progresso para um mundo que afunda em rigidez cadavérica?" (GS I, 682; TK $145 \mathrm{c} / \mathrm{i}$ ).

pergunta o crítico. Se a figura-cheve da alegoria barroca era o cadáver, a da alegoria modẹrna é a lembrança, relíquia em que "se condensa a crescente auto-alienação do homem, que faz o inventário de seu passado como um conjunto de bens mortos". A lembrança aparece como alegoria de uma memória morta, manifestação de "vivência", à qual o crítico opõe a "experiência" como forma de memória autêntica. Nostalgia e esperan. 
ça no futuro, esclarece Benjamin, são programaticamente evitados na poesia de Baudelaire. O "novo" que o poeta da Modernidade evoca em seus versos não significa "nenhuma contribuição ao progresso". Pelo contrário: pela maneira como a alegoria baudelaireana fala do tempo, ela se transforma em "antídoto contra o mito".

Do palco barroco à cidade surrealista

Para completar este informe sobre a relação entre drama barroco e gêneros literários urbanos falta ver os pontos de contato entre o "Trauerspielbuch" e os primórdios das "Passagens Parisienses", por volta de 1927-29. Os dois escritos benjaminianos mais significativos nesse período são o livro "Contramão" (Einbahnstrasse), publicado em 1928 e o ensaie "O Surrealismo. Ultimo instantâneo da inteligência européia", de 1929.

Diferentemente do livro sobre o drama barroco, hermético tratado filológico sobre uma dramaturgia feita por literatos de gabinete, com o peso de uma visão do Mundo como Biblioteca ou como Livro "Contramão", uma colagem de aforismas e instantâneos sobre a Cidade moderna, volta-se da cultura livresca para a cultura de rua. Um traço comum entre os dois livros é a importância atribuída à Escrita. Através da Escrita, mantém-se como constante a representação da autoridade e do poder, apenas mudou o cenário: do palco barroco para a cidade surrealista." Também em "Contramão", os fragmentos que compõem o livro são inteiramente alegóricos ,apenas mudou o tipo de alegoria: uma montagem de letreiros urbanos (placas de rua, tabuletas de toda espécie, out-doors, anúncios, avisos públicos, etc.) e de protocolos oníricos espera o leitor. O fragmento "Canteiro de obras" pode servir de iniciação. O que Benjamin diz aqui sobre o brincar, vale também para a atividade lúdica do escritor:

\footnotetext{
"As crianças têm uma tendência singular de procurar lugares de trabalho, onde se observa uma manipulação de coisas. Irresistivelmente, elas se sentem atraídas pelos resíduos, que nascem na construção, no trabalho de casa ou no jardim, nos trabalhos de costura ou de marcenaria. Nos resíduos, elas reconhecem a fisionomia do mundo das coisas, voltada para elas, só para elas" (GS IV, 93).
}

Do mesmo modo como o alegorista barroco em seu gabinete experimenta com combinações alquímicas de fragmentos, também o alegorista da Modernidade sente-se atraído pela experimentação com os resíduos da grande cidade contemporânea. Ao invés de "coisas", seu olhar pode se deter também em pessoas: os socialmente desprezados, o "lixo humano" da 
metrópole ("débris d'humanité"), de que fala Baudelaire no foema "Les petites vieilles". $\mathrm{Na}$ tradução benjaminiana do poema, publicada em 1923, chama atenção a beleza da 1. a estrofe (citada como epígrafe da II.a parte deste trabalho). O verso baudelaireano

"Où tout, même l'horreur tourne aux enchantements"

vem a ser, na versão de Benjamin:

"Wo Feen im Entsetzen selber walten"

(Onde fadas atuam em meio ao Terror).

um prenúncio do primeiro esboço das "Passagens Parisienses", de 1927, que tinham o subtítulo: "Eine dialektische Feerie" - "Uma composição feérica, dialética" .

Fada e Terror - sob essa imagem cambiante aparece a Metrópole moderna ao escritor Walter Benjamin nos anos 1920, e também aos surrealistas. O ensaio sobre o Surrealismo que visa, como o livro "Contra mão", a obter "a máxima concretude para uma época", contém, segundo Benjamin "algumas prolegomena do Trabalho das Passagens". Ele é, por assim dizer, a encruzilhada teórica entre "Trauerspielbuch" e "Passagens Parisienses". O fluxo das imagens barrocas é repensado, recondensado, redistribuído à luz da experiência da metrópole moderna. No culto das ruínas, das coisas desvalorizadas, quebradas ou vetustas, sensibilidade barroca e surrealista se correspondem.

"O surrealismo foi o primeiro a deparar-se com as energias revolucionárias que se revelam nas coisas 'antiquadas', nas primeiras construções de ferro ,nas primeiras fábricas, nas fotos mais antigas, nos objetos que começam a sair de circulação, nos pianos de cauda, no vestidos de cinco anos atrás, nos locais mundanos de reunião que começam a sair de moda. De que modo essas coisas se relacionam com a revolução? - ninguém melhor do que esses autores para explicá-lo. De que modo a miséria, não apenas a social, mas também a arquitetônica, a miséria dos interiores, as coisas escravizadas e escravizantes revertem em niilismo revolucionário - os videntes e visionários surrealistas foram os primeiros a percebê-lo" (GS II, 299; DCDB 109).

Não é preciso ir até o ponto de estilizar as coisas vetustas em portadoras de "energias revolucionárias", mas o potencial crítico das coisas antiquadas no contexto da Modernidade é algo irrefutável. No primeiro projeto das "Passagens Parisienses" anota Benjamin: 
"Moda como paródia do cadáver

...

"Moda - um diálogo com o corpo, e mesmo com a putrefação" (GS V, 1001).

A perspectiva pode ser invertida: o Cadáver como paródia da Moda. $\mathrm{O}$ espaço da Modernidade é invadido de atmośfera barroca. Numa imagem dialética, a Modernidade se "congela" e é identificada. A Modernidade sob o signo da Moda-Cadáver: uma cultura que vive obcecada pela fantasmagoria do Novo, sob a compulsão de ter que produzir, a qualquer custo, o Novo - um novo que é incessantemente desvalorizado por um novo mais novo. Uma cultura que não cria nada, apenas compulsoriamente desvaloriza. Tal o retrato da modernidade sob iluminação barroca .

Existe uma saída desse círculo infernal? No "Trabalho das Passagens", Benjamin se põe a descrever o "tempo infernal". O "último instantâneo da inteligência européia" parece ter sido tirado no momento imediatamente anterior Com a descrição do "tempo infernal", o escritor da Modernidade alemã acrescenta mais um traço à imagem da história como um "Trauerspiel". No ensaio sobre o Surrealismo, que faz parte de suas reflexões sobre a crise do inelectual nos anos 1920, ele entrevê uma saída, inspirada numa palavra de ordem do surrealista francês Naville: a organização do pessimismo.

\footnotetext{
"Pessimismo total. Desconfiança quanto ao destino da literatura, desconfiança quanto ao destino da liberdade, desconfiança quanto aos rumos da história européia, e sobretudo uma desconfiança total em todo tipo de entendimento: entre as classes, entre os povos, entre os indivíduos. $\mathrm{E}$ uma confiança ilimitada apenas na indústria bélica $\mathrm{e}$ no aperfeiçoamento da força aérea para fins pacíficos” (GS II, DCDB 114).
}

A organização do pessimismo - ou seja: a organização da Melancolia - tem na obra de Benjamin faces distintas, que dependeram das circunstâncias históricas e políticas. No período em questão, final dos anos 1920, coexistem em sua obra um temperamento militante e uma atmosfera feérica; a Modernidade como "Trauer-Spiel" não é apenas "luto", mas também "jogo". A atuação no "espaço imagético", o que Benjamin considera tarefa primordial do escritor, não consiste apenas em "derrubar a hegemonia intelectual burguesa e estabelecer o contato com as massas proletárias"; igualmente válida é a "iluminação profana" do leitor, do pensador, do homem que espera, do 'flâneur', do sonhador: 


\begin{abstract}
"No centro desse mundo [surrealista] das coisas está o mais sonhado de seus objetos, a cidade de Paris. ... Lá existem encruzilhadas ou cruzamentos onde brilham, de repente, no meio do trânsito, sinais espectrais; onde podem ocorrer a qualquer momento analogias inauditas e coincidências de acontecimentos. ... Mas é a revolta que faz com que se revele sua fisionomia surrealista (ruas desertas, onde apitos e tiros ditam a decisão). Nenhum rosto é tão surrealista como a fisionomia autêntica de uma cidade" (GS II, 300/301/300; DCDB 109/ $110 / 109)$.
\end{abstract}

$\mathrm{Na}$ cidade surrealista, o pequeno e o grande mundo, o mundo da experiência amorosa e dos negócios políticos, existem lado a lado. A Nadja de Breton é interpretada por Benjamin como a "voz das massas" metropolitanas. Eros e Pólis se entrelaçam. - O material onírico, fortemente usado no livro "Contramão" e nos textos dos surrealistas, parece à primeira vista um traço diferenciador entre poética moderna e barroca. No entanto, existe uma correspondência. A dispersão caótica dos utensílios, emblemas, alegorias é uma espécie de escrita tridimensional que projeta estados de alma num cenário confuso - tal como o trabalho onírico aproveitado pelos surrealistas.

Como se sabe, o sonho revolucionário dos intelectuais alemães foi derrotado pela realidade, e os escritores tiveram de mudar de estratégia. Para Benjamin, a organização literária dessa emoção - Melancolia ganhou então uma conotação mais sombria, mesmo assim não desprovida de sentido lúdico, auto-ironia e coragem. Diante de um mundo degradado e caduco, resistiu à resignação e registrou a imagem:

"O autor, no limiar da velhice, experimentou um daqueles momentos em que o homem, refletindo sobre sua vida passada, vê em tudo refletida sua própria melancolia. A pequena diminuição de sua visão, acusada na consulta ao oculista, fez com que se lembrasse da lei da inevitável caducidade das coisas humanas... Ele, que viajara pelo Oriente e se familiarizara com os desertos, cuja areia é pó dos mortos, teve de repente a idéia de que também esta efervescente cidade a seu redor deveria, um dia, morrer como morreram tantas capitais. ... Graças a uma lúcida intuição, que às vezes faz nascer um tema extraordinário, ele se propôs escrever o livro sobre Paris, que os historiadores da Antiguidade não escreveram sobre suas cidades..." (GS I, 589; TK $109 \mathrm{c} / \mathrm{i})$. 


\section{NOTAS}

(1) - Walter Benjamin, Gesammelte Schriften, 6 vols., Frankfurt, Suhrkamp, 1974-84. Todas as citações com a sigla "GS" referem-se a essa edição.

(2) - Bernd Witte, Walter Benjamin - der Intellektuelle als Kritiker, Stuttgart, Metzler, 1976, pp. 107-136.

Michael Rumpf, Spekulative Literaturtheorie. Zu Walter Benjamins Trauerspielbuch, Hanstein, Athenaeum-Hain-Skriptor, 1980.

(3) - A referência ao original alemão vem acompanhada da citação da tradução brasileira: W. Benjamin, Origem do drama barroco alemão, tradução, apresentação e notas: Sérgio Paulo Rouanet, São Paulo, Brasiliense, 1984; sigla "TR". Eventuais interpolações minhas nesta e nas demais traduções são caracterizadas com "c/i".

(4) - "DCDB" refere-se a W. Benjamin, Documentos de cultura - documentos de barbárie. Escritos escolhidos, seleção e apresentação: Willi Bolle, trad. Celeste Ribeiro de Sousa et al., São Paulo, Cultrix e Edusp, 1986.

(5) - Friedrich Nietzsche, Werke I, org. por Karl Schlechta, Frankfurt, Ullstein, 6 a ed., 1972 .

(6) - Bertolt Brecht, "Vom armen B.B.", in: Gesammelte Werke 8, Frankfurt, Suhrkamp, 1967, p. 263; v. também B. Brecht, Poemas 1913-1956, seleção, tradução e posfácio: Paulo Cesar Souza, São Paulo, Brasiliense, 1986, p. 66 .

(7) - Sobre a interpretação do conceito benjaminiano de alegoria como teoria da vanguarda, ver: Georg Lukács, Wider den missverstandenen Realismus, Hamburgo, 1958, e Peter Buerger, Theorie der Avantgarde, Frankfurt, Suhrkamp, 1974.

(8) - O texto "Parque Central" consta da antologia Walter Benjamin, Sociologia, org. e trad.: Flávio R. Kothe, São Paulo, Ática, 1985, pp. 123-152, citada a seguir "TK".

(9) - Para um retrato de Benjamin sob a ótica simultânea do Barroco e do Surrealismo, ver Susan Sontag, Sob o signo de Saturno, trad. Ana Maria Capovilla c Albin Poli Jr., Porto Alegre, LPM, 1986, pp. 85-103. 